\title{
Solid Waste Management: Mapping of Temporary Waste Sites and Potential Wild Solid Waste in Ternate City
}

\author{
Nani Nagu ${ }^{1}$ \\ Civil Engineering \\ Universitas Khairun \\ Ternate-Indonesia \\ ${ }^{1}$ nani.nagu09@gmail.com
}

\author{
Edward Rizky Ahadian ${ }^{2}$ \\ Civil Engineering \\ Universitas Khairun \\ Ternate-Indonesia \\ 2edoeny10@gmail.com
}

\begin{abstract}
Garbage is a classical problem faced by all cities in Indonesia. The same problem also found in Ternate due to various aspects including population growth and rapid urbanization, inadequate number of facilities, lack of landfill management systems based on environmentally, and the implementation of reduce, reuse and recycle are not running well. On the other side, the volume of disposal solid waste is increase every day. Meanwhile, the management of solid waste done by community involve burning, throwing to the river or ocean. Those practices raise the potential for wild solid waste everywhere. This research aims to identifying and mapping the location of Temporary Waste Sites (TWS) and wild solid waste location in Ternate City. In addition, this research also tries to provide solutions in order to improve waste management in the city of Ternate. The research data were obtained through direct observation and measurement in the field. Literature study is conducted as supporting data. The collected data will collaborate and processed to build the map using Geographical Information system. The result shows that the high source of solid waste in study area comes from urban settlement, while food leftover are the most waste in composition of solid waste. Moreover, the research found 107 locations of Temporary Waste Sites and 151 location of wild solid waste.
\end{abstract}

Keywords—solid waste; temporary disposal sites; wild waste;

\section{INTRODUCTION}

Waste can be defined as something that cannot be used, not liked or something that is wasted that comes from human activities and does not occur by itself [1]. According to the Law of the Republic of Indonesia Number 18 of 2008, waste is the remaining daily activities of humans and or a solid natural process. In SNI 19-2454-2002 in 2002, waste is solid waste consisting of organic and inorganic materials which are deemed useless and should be managed [2].

The problem of waste is no longer just a matter of cleanliness and the environment, but has become a social problem. Sometimes it is as trigger conflict among communities, stakeholders, and government. In Indonesia, the solid waste management conflict occurs not only in metropolitan cities but also in small cities. Ternate City as a small island and small town has continued to grow. Of course, various problems faced by local government including water shortages, population growth, and waste management. However, waste management is a crucial issue at this time.

Basically, solid waste management systems, especially for urban areas, must be implemented appropriately and systematically. Solid waste management activities involve the utilization of solid waste infrastructures and facilities which include storage, collection, transfer, transportation, processing and final disposal. The availability of waste management infrastructure such as Temporary Waste Site (TWS) is needed in terms of reducing the amount of waste disposed in any place. Unfortunately, the numbers of TWS are limited led to wild solid waste to be found everywhere.

Ternate city in the last ten years has experienced high population growth and economy. This condition triggers the increase of services, industry, and business activities. Directly, economic growth in Ternate city will contribute to increase in the production of waste. Besides that, inadequate number of facilities, lack of landfill management systems based on environmentally, and the implementation of reduce, reuse and recycle are not running well led to waste problem in this city [3].

The impact of wild solid waste can cause environmental damage, aesthetics and spread of disease in the community. This problem should be taken as soon as possible as a prevent practices step to reduce waste in the future. Therefore, this study aims to identifying and mapping the location of temporary waste sites and wild solid waste location in Ternate City. In addition, this research also tries to provide solutions in order to improve waste management in the city of Ternate.

Mapping the information has been widely used in various applications. This system utilizes remote sensing information or geospatial information to make it easier for users to read or analyze the conditions of an area. Easy to use, applicable, and covers a wide area is the advantage of this application. In this study, the mapping application is intended to determine the TWS and wild solid waste locations to facilitate future waste management planning. 


\section{MATERIAL AND METHOD}

\section{A. Study Sites}

Geographically, Ternate City is located at $0^{\circ}-2^{\circ} \mathrm{N}$ and $126^{\circ}-128^{\circ}$ E. Ternate city is a small island with the high volcano in the middle. The wide area of Ternate is 5,795.4 $\mathrm{Km}^{2}$ in which around $90 \%$ is ocean area and $10 \%$ is land area. While administratively, Ternate City as a part of North Maluku Province, consist of 8 islands where Ternate Island is the biggest Island. In addition, Ternate City divided into 8 sub-districts and 77 villages. $75 \%$ of those villages are coastal villages [4]. The map of study site is shown on fig.1.

As an island city, Ternate's topography varies from sea level. On elevation $0-400 \mathrm{~m}$ is the center of human activity, settlements, offices, and all buildings are standing at this area. Meanwhile, from $400-700 \mathrm{~m}$ is natural forest and conservation area. Unfortunately, the flatland area in this island is limited but development intensity increases every year [5].

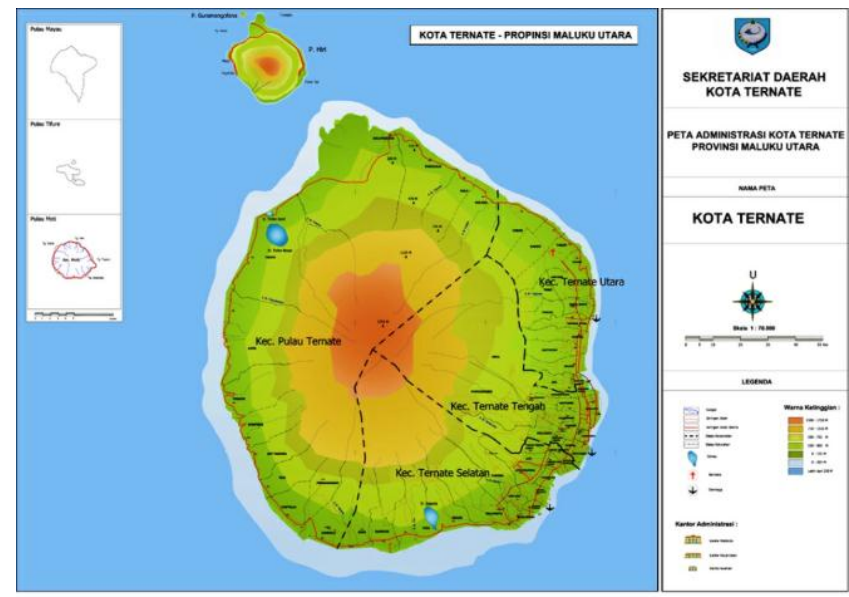

Fig. 1. Study Sites

The population number of Ternate City in 2016 reaching 218,028 people. It is divided to 110,725 men and 107,303 women. This number has increased $2.36 \%$ compared to in 2015 which reached 212,997 people. While, population density in Ternate City in 2016 was reach 1,345 people per $\mathrm{km} 2$. Population density in 8 sub-districts is quite unequal with the highest population density found in Ternate Tengah sub-district at 5,699 people per $\mathrm{Km}^{2}$ and the lowest found in Pulau Batang Dua sub-district at 97 people per $\mathrm{Km}^{2}$. The uneven distribution of population in Ternate city due to the concentrated population in areas that are central government activities, economy, education and other activities.

Based on the results of the national socioeconomic survey in 2016, it was found that $2.67 \%$ of Ternate's population was below the poverty line at 489,810 rupiahs. This poverty line increased by $6.58 \%$ from the previous year 459,551 rupiahs. This shows that residents in Ternate City who have income below the poverty line can be classified as poor [6].

\section{B. Research Procedures}

This research is a descriptive research in which trying to explore the data systematically, factually, and accurately about the characteristic, composition, and location of temporary waste disposal. This research take focus on four sub-districts in Ternate Island such as; North Ternate subdistrict, Central Ternate sub-district, South Ternate subdistrict, and Island Ternate sub-district.

Both primer and secondary data are essential in this research. Primary data is obtained through direct observation and measurement in the study area. Coordinate point of each TWS and wild solid waste done by tracing each sub-district which is the object of research using the available road access. To get the coordinate of TWS, Garmin GPS 64s was used. All primary and secondary data that have been collected will show on descriptive and systematic through the map.

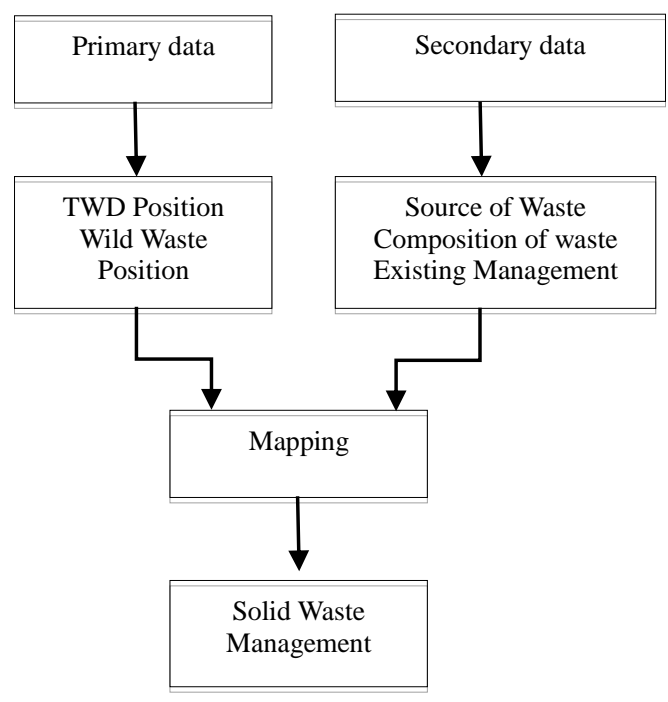

Fig. 2. Research Prosedure

\section{RESULT AND DISCUSSION}

\section{A. Preview of Waste Management in Ternate City}

Waste management is a system where involve many parties. Basically, this system starts from waste producers (such as households, markets, institutions, industries, etc.), managers (contractors), regulators, the informal sector, and communities. Next the system involves the manager (government or private sector). Therefore, the solution of the waste problem also requires a comprehensive approach and the involvement of all stakeholders.

In Ternate, the institution who is responsible for solid waste management is the Regional Environmental Agency. This agency has responsible to implementation of technical policy, coordinating the environmental protection, biodiversity and natural resources. This agency also 
arranges pollution control and environmental impact assessment [7].

Collecting, transporting and disposing are the old paradigm of waste management. While, the new paradigm is sort and process the waste starting from the sources. At this moment, the environmental agency in Ternate City still use old paradigm in terms of waste management. The illustration of waste management in Ternate City is shown on fig. 3. Meanwhile, the application of new paradigm in Ternate City is still face some problems. Those problems involved operational and technical aspects; institutional, organizational and management aspects; financing aspects; regulation aspects, and community participation.

From operational and technical aspects, lack of infrastructure and facilities are the main problems. Based on the data from Regional Environmental Agency, the number of waste truck that they have is 22 units, 6 unit motorcycles, 8 unit pick up cars, bulldozer 2 units, and excavator 2 units [7]. While on institutional, organizational and management aspects, the main problem is human resources. Furthermore, lack of community participation in waste management is also the major problem.

From regulation and financial aspects, the government of Ternate has been produced the regulation of solid waste management. Unfortunately, the implementation of this regulation is not running well. E.g. giving the reward to the people who care to environment and punishment to who is damaging environment.

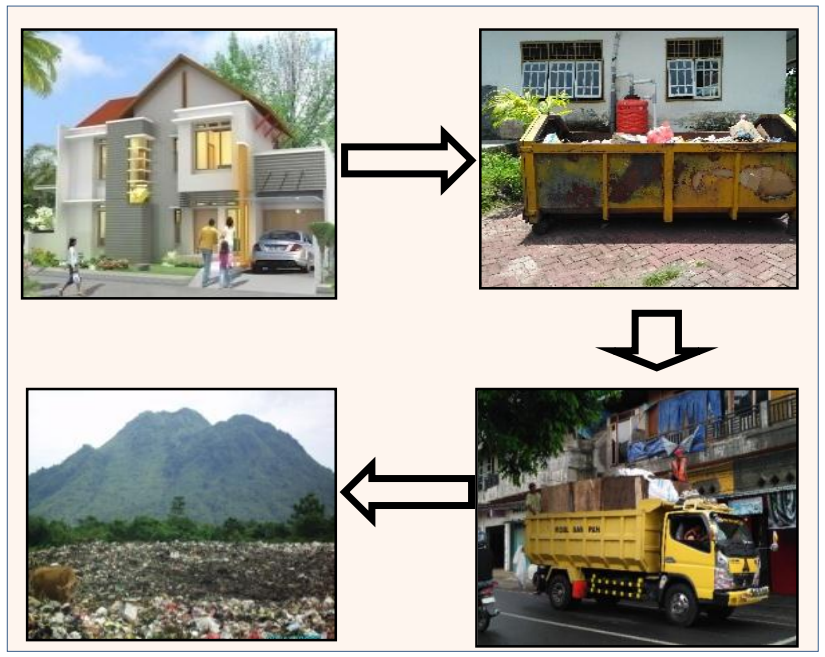

Fig. 3. The Ilistration of Solid Waste Management in Study Area

In addition, the waste collection system applied is not optimal, especially household waste, where collection activities are only carried out in residential areas on the side of the protocol road. The collection carried out by the community in this area by using plastic trash cans, plastic bags or concrete pairs in the form of TWS. The ease of transport factor for the lanes that can be traversed by garbage trucks. For dense residential areas that are difficult to reach by garbage trucks or far from the trash of garbage trucks, difficulties often occur for residents. This condition is almost found in all dense residential areas, especially those with high topography.

\section{B. Source of Waste and Its Characteristics}

The condition of solid waste services in Ternate City is about $361.84 \mathrm{M}^{3}$ per day. While the waste that entering the landfill every day is $559 \mathrm{M}^{3}$ per day. Meanwhile, the volume of waste produced by community activities every day covers $65 \%$ of 59 villages [7].

The production of waste in study area is increase every year. In 2011, the production of waste reach $173.543 \mathrm{~m} 3$ per year and it is growth $6 \%$ in 2015 at $203.950 \mathrm{~m} 3$ per year. The rising of waste disposal has strongly related to growth of population. In 2011, the population in Ternate City was 190.184 people and in 2015 reaches 223.507 people [4]. The information of waste production in study area is shown on table 1.

TABLE I. WASTE PRODUCTION IN TERNATE CITY

\begin{tabular}{|c|c|c|c|c|}
\hline \multirow[t]{2}{*}{ Year } & \multirow{2}{*}{$\begin{array}{c}\text { Population } \\
\text { Number }\end{array}$} & \multicolumn{2}{|c|}{ Waste Production } & \multirow{2}{*}{$\begin{array}{c}\text { Services } \\
\text { level }\end{array}$} \\
\hline & & $M^{3} / d a y$ & $M^{3} / Y e a r$ & \\
\hline 2011 & 190.184 & 475 & 173.543 & $59 \%$ \\
\hline 2012 & 191.053 & 478 & 174.813 & $60 \%$ \\
\hline 2013 & 202.728 & 507 & 184.989 & $64 \%$ \\
\hline 2014 & 213.425 & 534 & 194.750 & $63 \%$ \\
\hline 2015 & 223.507 & 559 & 203.950 & $65 \%$ \\
\hline
\end{tabular}

Waste disposed is the amount of waste produced from domestic and non-domestic waste in units of volume or weight per unit time. The understanding of source of waste is important way to determine the amount of waste that should be managed.

Waste disposed is the amount of waste produced from domestic and non-domestic waste in units of volume or weight per unit time. The understanding of source of waste is important way to estimation of waste disposed to determine the amount of waste that should be managed. Refers to source of the waste in study area, in 2016 this research found that the settlement has the high production of waste $(35.68$ ton per day). In second places is traditional market (8.12 ton per day) and business places in third position (5.66 ton per day). The percentage of waste sources in study area is presented in Fig.4.

Meanwhile, figure 5 shows the composition of waste produced in Ternate City. From this table, it can be seen that organic waste is dominant at $53.96 \%$, while inorganic waste is $46.04 \%$. The organic materials are including food, wood, tree branch, and leaf. Furthermore, inorganic materials are including plastic, metal, rubber, glass, fabric, and others. 


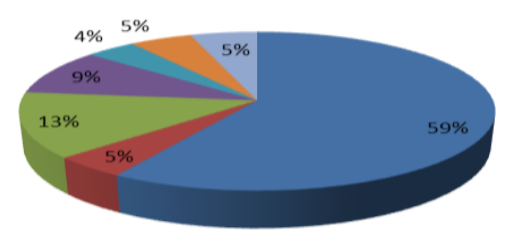

- Settlement m Offices - Traditional market - Business - Public facilitie = industrial area wothers

Fig. 4. The Percentage of Waste Sources in Study Area

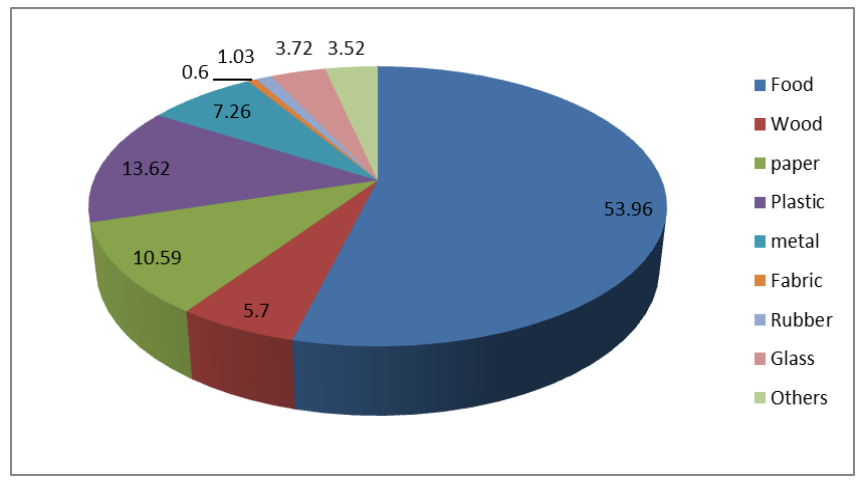

Fig. 5. The Percentage of Waste Composition in Study Area

Furthermore, the volume of transported waste is then carried out by several processes. Waste processing is an activity intended to reduce the amount of waste, besides utilizing the value that is still contained in the waste itself (recycled materials, other products, and energy). Waste processing can be done in the form of: composting, recycling / recycling, incineration, and others.

By waste management institutions, landfill is the most frequent process. in 2015, the amount of organic and inorganic waste processed by landfilling reaches 45.82 ton per day and toxic waste only 0.6 ton per day. It is descrease to 42.5 ton per day in 2016. Moreover, composting, burning, and recycle are the others way of waste processing in study area. However, those processes are a new methods. The processes of waste processing in study area is shown on table 2 .

TABLE II. WASte Processing IN Ternate City

\begin{tabular}{|l|c|c|c|c|c|c|}
\hline $\begin{array}{c}\text { Processing } \\
\text { Methods }\end{array}$ & \multicolumn{2}{|c|}{ Organic Waste } & \multicolumn{2}{c|}{ Inorganic waste } & \multicolumn{2}{c|}{ Toxic waste } \\
\hline Year & 2015 & 2016 & 2015 & 2016 & 2015 & 2016 \\
\hline Recycle & 0 & 0 & 1,54 & 4,3 & 0 & 0 \\
\hline Composting & 0,63 & 2,56 & 0 & 0 & 0 & 0 \\
\hline Burning & 0 & 0 & 0 & 0 & 0 & 0 \\
\hline Landfill & 21,81 & 23,34 & 24,01 & 19,16 & 0,6 & 0,73 \\
\hline Others & 5,17 & 5,71 & 5,84 & 4,84 & 0 & 0 \\
\hline
\end{tabular}

\section{Location of Temporary Waste Sites and Wild Solid Waste}

TWS is a facility located close to a residential or commercial area. TWS is used to receive and accommodate garbage from collection vehicles so that it can be transferred to a larger transfer vehicle to the landfill, processing center or composting facilities. Sometimes TWS also provides waste sorting and recycle facilities [8]. Actually, TWS built by government or private sector used concrete or wood material. Usually, it consists of one or two compartments. The function compartments as separation of waste composition. On the other hand, in order to selecting TWS should include evaluating some of the following variables: distance to the main road, distance to the river, and buffering at around the trash bin.

TWS has several advantages because the use of TWS can reduce the number of garbage transport vehicles and reduce user traffic and air pollution. In addition, it also allows reducing wild solid waste and facilitating landfills in remote area. Therefore, TWS has an important role in the waste management system.

Based on the survey result, temporary waste disposal sites in Ternate City were generally concentrated in Center Ternate sub-district (32 units) and South Ternate sub-district (48 units). Whereas in North Ternate sub-district, the number of TWS only 12 units and Ternate Island sub-district is 15 units. Lack of TWS in North Ternate and Ternate Island Subdistricts is caused by the fact that most people still have large land areas as landfill and the production of waste in those areas are still low. Fig. 6 illustrated the distribution of TWS in study area.

The TWS location is ideally located in an area far from the settlement so that it does not disturb the comfort of the surrounding community. However, those found at the study location, generally the location of the TWS is directly adjacent to the residential area and is located beside the road. Unfortunately, the conditions of TWS in Ternate City are very concerning. Most of TWS had damage in walls, placement of locations that are not suitable, and does not use a container cover.

Furthermore, wild solid waste is a garbage collection that is placed not in the TWS. Wild solid waste is usually placed on the side of a road, river or other place. This pile will greatly disrupt cleanliness and cause environmental pollution. Garbage placement at wild solid waste is closely related to the availability of TWS and community behavior. The habit of the people in Ternate city who do not care about garbage causes them to throw their trash in a place that is easily accessible. Sometimes, the garbage is dumped beside the house, river or sea. This certainly leads to a lot of wild solid waste generation in the city of Ternate.

The distribution of wild solid waste location is closely related to population distribution in sub-district area. The study results found that wild solid waste was found most in areas with high population density. But the wide area of subdistrict has less influence on the number of wild solid waste. Most of wild solid waste locations found in Center Ternate sub-district with 70 places. Next is in South Ternate subdistrict with 37 places, followed by Ternate Island subdistrict with 29, and the last in North Ternate sub-district with 15 places. Fig. 7 illustrated the distribution of wild solid waste location in study area. 


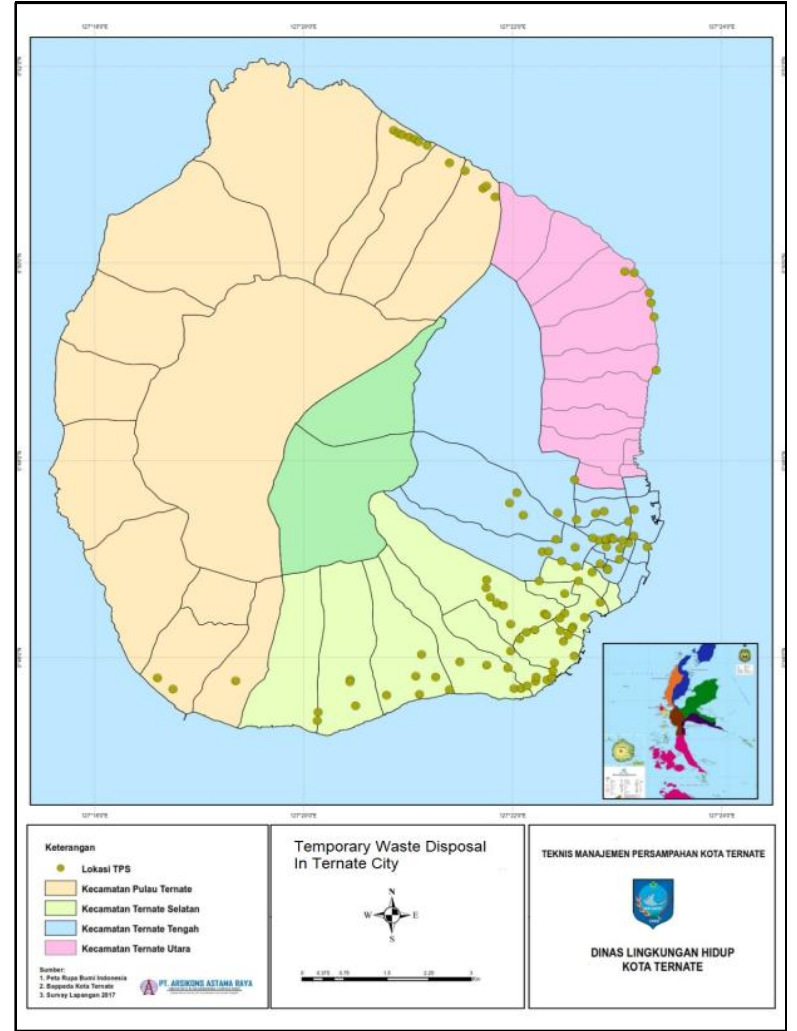

Fig. 6. The Temporary Waste Site in Study Area

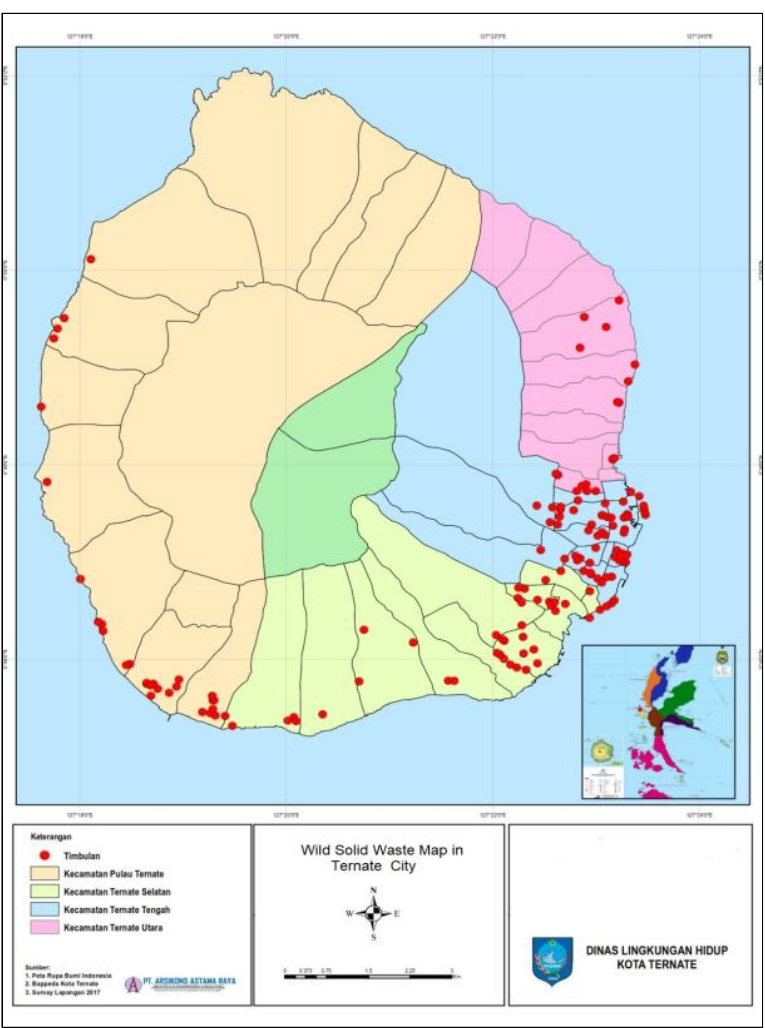

Fig. 7. The Wild Solid Waste location in Study Area

\section{CONCLUSION}

The existence of TPS as a garbage collection tool before being transported to the TPA often becomes a polemic. sometimes, residents reject the placement of polling stations in front of their homes. this has implications for many wild waste generations. The condition of TPS that is not covered is also a source of foul odors and disease vectors from flies and mice. As a result, it is often found that waste generation is very aesthetically very disturbing. therefore, the government is expected to be able to take technical appointments to reduce the piles of garbage in TPS and WSW. steps that can be taken include; 1) Changes in the mindset and behavior of the community in waste management through social engineering programs. 2) Increase waste reduction at the planning and programming stages, and 3) Carry out monitoring and evaluation in order to improve the performance of waste reduction and handling.

\section{REFERENCES}

[1] B. Chandra, Pengantar Kesehatan Lingkungan. Jakarta: Buku Kedokteran EGC, 2007.

[2] SNI 19-2454-2002, Tata Cara Teknik Operasional Pengelolaan Sampah Perkotaan, 2002, downloaded from http://ciptakarya.pu.go.id.

[3] M. Rengkung and W. Fella, "Analisis Sistem Persampahan di Kota Ternate," Sabua, vol.6, pp. 351 - 362, November 2014.

[4] Biro Pusat Statistik, Kota Ternate dalam Angka Tahun 2016, 2016, downloaded from https://ternatekota.bps.go.id.

[5] Badan Perencanaan Pembangunan Daerah, Rencana Tata Ruang Wilayah Kota Ternate 2012-2032, 2012, downloaded from http://bappeda.kota-ternate.go.id/rtrw-kota-ternate/

[6] Biro Pusat Statistik, Indeks Pembangunan Manusia Provinsi Maluku Utara tahun 2016, 2017, downloaded from https://malut.bps.go.id.

[7] Dinas Lingkungan Hidup Kota Ternate, "Perencanaan Teknis Manajemen Persampahan Kota Ternate," unpublished.

[8] Aryenti and T Kustiasih, "Kajian peningkatan tempat pembuangan sampah sementara sebagai tempat pengelolaan sampah terpadu Increasing of Temporary Disposal Site as an Integrated Waste Management”. J. Permukim., vol. 8, pp. 88-97, Agustus 2013. 